\title{
地理教育総説記事
}

\section{地誌学習再考 \\ Reconsideration of Regional Geography Education}

\author{
秋本 弘章 \\ AKIMOTO Hiroaki
}

日本における地誌学習を, 学習指導要領を中心に検討した。 日本では, 児童・生徒に諸地域の実態を知 識として身につけさせることを目的にカリキュラムを構成してきた. 平成 10 年告示の学習指導要領では 地域の特徵を解明する方法を学ぶことがカリキュラムの中心となった. このことに批判があったが, 本来 この二つは, 相互に補完するものである. 日本の地誌学習は欧米の地誌学習と比較した場合, 特殊な面を 持つが, 方向性は共有している. 日本の地誌学習の課題は, 教育現場での実践にあるが, 教員だけの問題 としてとらえるのではなく, 教育環境も含めた教育システムの問題としてとらえる必要がある.

The author has reviewed regional geography education centering upon the course of study in Japan. In Japan the curriculum has been constructed with a view to have students acquire knowledge about the actual conditions of regions and the world. In the case of the course of study announced in 1998, the curriculum was made to center on the ways to find regional characteristics. Essentially, these two approaches are complementary to each other. Regional geography education in Japan, as compared to in Europe and USA, has some unique aspects all right but its direction is just the same. While the challenge of regional geography education in Japan is at its practical stage, it has to be seen not as the problem in the field of school education but, instead, as the problem of educational system.

キーワード : 地誌学習, 学習指導要領, 知識重視, 方法重視

Key words: regional geography education, course of study, knowledge about regions and the world, the ways to find regional characteristics

\section{I はじめに}

近年の中学校学習指導要領及び高等学校学習指 導要領の改訂で最も大きく変化したのが地誌学習 である。

地誌学習は, 日本や世界各地の事情を情報とし て児童・生徒に伝達するとともに，世界認識を育 てる役割を果たしてきた(荒木 2006). グローバル 化が急速に進む今日，必要とされる情報や知識も 格段に増加するようになった。地誌学習の役割は 一層増しているように思える。

一方，マスコミやインターネット等を通じて日 本や世界各地の情報が多量にもたらされるように なっていること，変化の激しい現代社会において
は，日本や各地の事情が変化する可能性が高いこ とを考えると，日本や世界各地の事情を情報とし て伝えることのみを目標とするならば，その意義 が疑われても仕方があるまい(西脇 1993).

では, どのような地誌学習を構築すべきなのか. 近年の地誌学習を巡る動きは，こうした社会状況 の変化を受けたものとも考えられる. 本稿では, 日本におけるこれまでの地誌学習の動きを学習指 導要領に基づき整理したうえで，今後の地誌学習 の在り方を検討する.

\section{II 「地誌」「地誌学」と「地誌学習」}

「地誌」と「地誌学」は同義に使われることも 
あるが，詳細に検討すれば違いがある.

わが国の最も古い「地誌」は「風土記」といわ れる。これは各地の事情を網羅的に記載したもの で，為政者が統治の目的で作成した。 民主主義社 会では，こうした情報を広く一般に知らせる必要 がある. 都道府県では都道府県勢要覧などを作成 しているがこれは現代版の「地誌」といえる。ま た, 後述する「地誌学」の成果も, 「地誌」であ る、つまり,「地誌」は地域の実態を情報として 伝達することを目的に記載されたものである.

一方「地誌学」が成立したのは 19 世紀である. 「地誌学」は, 特定の地域における地域的特徵を総 合的に究明することを目指す地理学の一分野であ るとされる. 地域的特徽の究明という目的を達成 するためには, 地域を構成する様々な事象につい て観察や測定, 聞き取り等の調査がなされ, それ らのデータをもとに, 各事象間の関連性の検討や 他地域との比較が行われる.こうした調査・分析 を通じて地域的特徴を明らかにする.

「地誌学習」は「地誌」と「地誌学」の双方を基 盤とした学習である。しかし,「地誌」と「地誌 学」の違いは, 当然学習の方法の違いに反映され る.「地誌」を基盤とした場合, 情報伝達や内容 理解に学習の重点が置かれるのに対して, 「地誌 学」を基盤とした場合は, 視点や調査・分析, つ まりプロセスに学習の重点が置かれる. 白井 (2000)は, 前者を「地誌学習」, 後者を「地誌的 学習」と呼び区別しているが, 本稿では, 前者は 「知識重視の地誌学習」, 後者は「方法重視の地誌 学習」と呼ぶことにする. 当然のことながら,「地 誌学習」はこの両者を含んで行われてきた.

\section{III＼cjkstart地誌学習の役割}

「高校生の 6 割『宮崎どこ?』」2008 年 3 月 20 日新聞各紙が, 日本地理学会地理教育専門委員会 が高校生と大学生を対象に行った調查結果(2008) を報道した。（財）総合初等教育研究所(2008)によ れば，小学生でも同様な結果が得られたという。 こうした実態を問題視する意見は多く, 中央教育 審議会答申(2008)にも反映された. これは, 地誌
学習に期待される基本的な役割を示している. つ まり, 日常生活に必要な日本や世界についての基 礎的な地理的知識を身につけさせるという考え方 である。

地理的知識を身につけさせることは, 日常生活 で必要ということは確かであるが, 教育で扱う意 義はそれにとどまらない.グールドとホワイト (1981)によれば，人間は頭の中に何らかの地図を 作り，それをもとに意思決定をするという。つま り，民主主義社会の一員としてふさわしい意思決 定ができる人間の育成のために, 望ましい頭の中 の地図, 寸なわち, 地域認識, 世界認識を形成さ せることが重要で, これこそが地誌学習の真の役 割ということができる.

身近な地域であれば，経験的・体験的に地理的 知識を獲得することができ, それをもとに地域認 識を形成させることも可能であろう。しかし，日 本や世界を対象にすると, 間接的な情報をもとに 地域認識や世界認識を形成させるしかない. 現代 では, マスコミやインターネットの発達によって, 地域認識や世界認識の基となる日本や世界各地の 情報の入手が容易になった。 しかし, それらの情 報には偏りがある。したがって, 学校における地 誌学習では, 児童・生徒に日本や世界のバランス の取れた情報を与え, 的確な地域認識, 世界認識 を形成させることが重要であると考えられる。

こうした地誌学習の意義は斎藤(2003)も指摘し ている. すなわち, 学校における地誌学習は, 身 近で体験的な世界から直接体験することのできな い世界への興味・関心を広げ，幼児の持つアミニ ズム的世界観から科学の支配する世界観への転換 を迫る上で重要な役割を担うという。

一方, 知識の習得よりも見方・考え方の習得を 重視する立場も古くからある. 矢嶋(1977)は, 地 誌学習の目標を, 地表面に展開寸る様々な地理的 事象を正しくとらえ, 事象相互の関係や人と環境 との結びつきなどを考察して, 地域に立脚しての 見方や考え方を育成し，わが国土と世界について の広い視野を培うことにあると述べている。つま り, 知識よりも方法としての見方や考え方の習得 に重きを置いている. 


\section{IV 学習指導要領からみた地誌学習の変遷}

日本の学校教育における地誌学習, 特に小・中 学校では, 日本や世界各地の事情の伝達と世界認 識の育成を目的としてきたことから，「知識重視 の地誌学習」を中心に展開してきた。 世界や日本 をいくつかの地域に区分したうえで, 各地域の状 況を理解させていくという学習のやり方である. 一般に, 日本では北海道, 東北, 関東といった 7 地方区分が，世界ではヨーロッパ，アジア，北ア メリカ, 南アメリカ, アフリカ, オセアニアとい った区分が用いられ，それぞれの地域の事情を説 明してきた。しかし, 「知識重視の地誌学習」に はいくつかの問題点が内在する.

日本や世界のバランスのとれた知識を与えるた めには，できるだけ多くの地域を扱うことが望ま しい(白井 2000). しかし, 学校における学習時間 は限られているから，多くの地域を扱おうとすれ ば，表面的な学習にとどまらざるを得ない。結果 として，羅列・網羅的で暗記重視の学習を助長さ せてしまう。しかも, 羅列・網羅的で暗記を重視 する学習では, 児童・生徒に世界認識を形成させ ることが難しい。 なぜなら，世界認識とは，個別 の地理的知識ではなく, 相互に結びついて, 体系 化された知識だからである。認知科学でいえば, 長期記憶に属するものである(小林 1996). 世界認 識形成のためには, 地域の諸事象を, さまざま角 度から分析, 考察することと, 繰り返し参照する ことが必要なのである.

篠原(1984)によれば世界認識の育成には 4 つの 段階があるという.すなわち, 興味・関心の段階, クイズ的知識の段階, 科学的理解や認識の段階, 客観的・科学的認識を踏まえた主体的認識（自己 認識も含む）の段階である。興味・関心の段階や クイズ的知識の段階では, 羅列・網羅的な学習も 有効であるが, 科学的理解や認識の段階以上では, 調査や分析, 考察といった, 「方法重視の地誌学 習」を取り入れることが不可欠となる.

「方法重視の地誌学習」では, いくつかの概念が 重視される. 重要な概念のひとつが,「一般的共
通性」「地方的特殊性」であろう。1953 年にシェ 一ファーが「地理学における例外主義一その方法 論的吟味」という論文を発表した. 従来の経験主 義的な記述を中心とする地理学を批判し, 空間的 法則性の解明を目的とし，地域研究は検証の場と するという考え方を主張したのである(手塚 1988). この論文が発表されたわずか 2 年後, 昭和 30(1955) 年告示の中学校学習指導要領に「一般的共通性」 と「地方的特殊性」という用語が記述されている. 欧米の地理学思想の潮流をいち早く取り入れた画 期的なものといえる. しかも, 系統地理学習では なく，地誌学習でこうした見方を具現化させてき たという点でも特筆に值する。

地誌学習の中で, 「一般的共通性」や「地方的 特殊性」の把握の方法としてまず採用されたのは 「静態地誌」といわれる方法である.この方法では, 地域を構成する地理的事象をできるだけ広く取り 上げ，それらを説明する。他の地域においても同 じように説明したうえで，それらを，比較対照す ることによって各地域の特性を把握する．伝統的 な地誌の記述や地域統計の利用を考えると, 大変 有効であると考えられるが, 特定の地域の学習段 階では羅列・網羅的な学習が進むきらいがある. また, 限られた学習時間では地域性の解明に到達 しないこともあったと考えられる。

次に採用されたのが，「地域抽出法」である. 「範例学習」あるいは「サンプルスタディ」ともい われる。これはある地域を学習する際, その地域 を構成する一部の地域を取り上げて詳しく分析す ることで，地域全体の理解につなげていこうとい う方法である。ある地域の「地方的特殊性」は, その地域を構成する部分地域の「一般的共通性」 となって表れていると考えるわけである。この方 法の学習上の利点は, 国家のような比較的規模の 大きい地域の学習において具体的なイメージをつ かみやすい小規模の地域を扱うということにある。 昭和 43(1968)年告示小学校学習指導要領では, 世 界の気候区分をもとに, 熱帯地方の生活や極地や 寒冷な地方の様子, 乾燥した草原や砂漠の生活な どが具体例として取り上げられた。

「地域抽出法」と並んで「動態地誌」という方法 
も採用された。 これは, 地域を構成する様々な事 象のうち重要と考えられる事象を取り上げ，それ を他の事象と結び付けながら説明していくという ものである，個々の事象は，多かれ少なかれどの 地域でも見出すことができる。しかしながら，そ れぞれの事象の関連の仕方に地域の特性があると 考えるのである。この方法では，取り上げる事象 によって地域の見え方は異なってくるという問題 点はあるものの, どのような事象を取り上げるか という考察，さらには取り上げた事象が他の事象 とどう関連しているかという検討は, 地域構造を どうとらえるかということにつながっているので, 地域に対する見方を涵養することになる，この方 法は, 昭和 44(1969)年告示中学校学習指導要領の 内容の取扱いに記載された.

「方法重視の地誌学習」においては, スケールの 概念も重要である。なぜなら，スケールによって 観察し, 調査分析する内容が異なるからである. 例えば，自然堤防や後背湿地といった沖積平野の 小地形は市町村以下のスケールでしか観察できな い. 一方, 日本の山脈などをプレートの動きとの 関連で理解しようとすれば地球規模での視点が必 要である。また，スケールが異なれば，調査分析 方法も異なる. 市町村以下のスケールでは, 観察, 測定, 聞き取りなどの直接調査を行い, それに基 づいた分析・検討が行われる。しかし, 都道府県 や国, 州・大陸, 世界といったスケールでは, 直 接調査は不可能で, 統計や文献, 衛星画像, 地図 などの資料分析が中心になる。

昭和 30(1955)年告示および昭和 33(1958)年告示 中学校学習指導要領の「郷土」「日本の諸地域」 「全体としての日本」「世界の諸地域」「全体とし ての世界」という内容の枠組みは, 郷土一地方一 国一州・大陸一世界というスケールを意識して構 成されたとも考えられる。

以上みてきたよう日本の地誌学習は「知識」で カリキュラムを構成し,「方法」が補完するとい う形で進展した。 しかし, 平成 10(1998)年告示学 習指導要領に至って「知識」と「方法」が逆転し た。平成 10(1998)年告示の中学校学習指導要領で は, 網羅的な諸地域学習がなくなり, 身近な地域
一都道府県一国一州・大陸というスケールを重視 した構成がとられたのである。平成 20（2008）年 告示中学校学習指導要領においては, 「方法重視 の地誌学習」への批判もあって, 再び「知識重視 の地誌学習」が中心となった.

高等学校においては，系統地理学習が中核であ った. 昭和 45 （1970）年告示の高等学校学習指導 要領では, 系統地理学習を中心とする地理 A と, 「知識重視の地誌学習」の性格が強い地理 B $の 2$ 科目が設置された。しかし, 昭和 53（1978）年告 示の学習指導要領以降は, 1 つの科目の中に系統 地理学習と地誌学習が併置されたことから, 地誌 学習では, 事例学習, すなわち「方法重視の地誌 学習」が中心となっている.

\section{$\mathrm{V}$ 「方法重視の地誌学習」の意義と課題}

平成 10（1998）年告示の中学校学習指導要領に おいて「方法重視の地誌学習」でカリキュラムが 構成された要因は, 学力観と教育課程の変化であ る。いわゆる詰め込み教育への批判と「ゆとり」 を求める世論の高まりから, 授業時数と学習内容 が削減された。地誌学習も対応が求められた。

「知識重視の地誌学習」では, 各地域がそれぞれ ユニークな存在であるという前提に立っている. そのため，ある地域を学習したところで，他地域 の理解には直接つながらない。つまり,「内容重 視の地誌学習」ではすべての地域を扱うことが必 要となる。したがって,「知識重視の地誌学習」 で授業時数を削減するには, 地域単位を大きくし て地域数を減らすか, 各地域の学習内容を削減す るしかない。ただ，地域単位を大きくすると内部 差も大きくなる，学習が進み，より詳細な事実の 検討がなされるようになると，こうした方法は難 しい。また, 各地域の学習内容の削減は, 地域の 多面的な検討を困難にし，表面的な理解にとどま ってしまう可能性が高い.

「方法重視の地誌学習」では, 2 つの対応が可能 である。ひとつは，現代における地誌研究すなわ ち「地域研究」の方法の採用である. 矢ヶ㠃 (2003) によれば，地域研究者は地域との交流と模索の中 
で研究課題を設定し, フィールドワークなどの調 查研究を行うことで地域の理解を目指していく. さらに，こうした地域の理解を通じて世界認識の 枠組みを構築していくという。つまり, 特定地域 の詳細な研究が世界認識の出発点と考えるのであ る.この研究方法を地誌学習に取り入れるとすれ ば，学校においては，児童・生徒が興味・関心の ある地域を選択し, その地域の調査や研究の疑似 体験を通じて，地域理解をはかることが目標とな り，世界認識は生涯学習での課題となる。児童・ 生徒の興味・関心を出発点とし, 調査・研究とい う体験を通じて自らの世界認識を形成していくと いう方法は構成主義の考え方にも通じている。ま た，「学び方を学ぶ」という近年の教育の方向性 とも一致している．ただし，この方法を採用する 場合，生涯学習を通じた地誌学習の構築が必要と なる、だが, 教育政策として生涯学習の重要性は 示されているものの, 必ずしも具体化されている とは言えない.

もうひとつは，「地域区分法」の採用による学 習対象地域の選択である。地域区分とは，全体地 域を概観したうえで，何らかの指標をもとに地域 を分類していく作業である，地域区分の過程にお いて，各地域が他の地域とどう違うのか，各地域 がどういう特性を持っているかが明らかになる。 そのうえで，特定地域を学習対象として選択寸れ ば，全体地域の中での位置が明確となり，学習対 象として選択する意味づけもなされることになる. したがって，世界認識の育成という目的を維持し つつ，学習対象地域を選択するために，「地域区 分法」は優れた方法であるといえよう.もちろん， 地域区分は取り上げる指標や地域の見方によって， いくつもの区分が考えられる。つまり, 地域区分 の学習は, 区分された地域を所与のものとして記 憶定着させることではなく，区分の目的とそれに 対応した地域の見方を理解させることに主眼が置 かれることになる。

ところで,「方法重視の地誌学習」では, 生徒 が調査や分析を行って地域性を見出すという学習 活動が中心になる。それは教員がすでに明らかに された地域性を説明していくよりはるかに指導が
難しい。児童・生徒ごとに学びの対象地域も注目 する地域事象も異なる。当然，一斉授業で行うに は限界があり, きめ細やかな指導も必要となる。 また，情報化が進み，多くの資料等がインターネ ット等を通じて入手可能になったとはいえ，児 童 - 生徒の調査 ・研究に真に必要な資料が十分に 提供されているとは言えない。つまり，「方法重 視の地誌学習」を展開するには, 学習環境の整備 が極めて重要である.

また, 日本の地理教育全体を見渡した場合, 「方 法重視の地誌学習」は, すべての学校段階で有効 とは言えない。一般に, 小中学校の段階では日本 や世界についての経験や知識がそしいので，興 味・関心を喚起するような学習が重要である。同 時に, 地図を見る習慣をつけさせ, 基礎的な知識 の定着を図る必要がある。したがって, 「知識重 視の地誌学習」が中核にならざるを得ない。

従来の地誌学習が暗記重視と批判されたのは, 「基礎的」な知識の内容を限定しなかったことにも 原因がある。地理に詳しいと言えば，地域の事情 に詳しいという言葉で語られることから，学校段 階が進むと広範囲にわたって詳細な知識を与える 傾向にあった。逆に，暗記重視と批判が高まると 全く暗記を求めない状況が出現した.

これまでも「基礎的」な知識について議論がな されてきた（例えば岩本 2000）。日本地理学会地 理教育専門委員会による高校生・大学生の地理的 認識の調査 (2005) 以後, 基礎的な地理的知識の 定着についての関心は高まった。平成 20（2008） 年告示の小学校学習指導要領には 47 都道府県の 名称と位置(第 3 学年及び第 4 学年), 世界の主な 大陸と海洋, 主な国の名称と位置, わが国の位置 と領土(第 5 学年), 中学校学習指導要領には主な 国の名称と位置と記載され, さらに中学校学習指 導要領解説には, 数の上では, 世界の 4 分の 1 か ら 3 分の 1 程度の国々の名称と位置が一応の目安 になると基準が示されることとなった．

ところで, 山口（1994）は「名称知識」は小学 生から中学生にかけて伸びるが，「位置知識」は 小中学生より高校生で伸びることを指摘している. 「位置知識」は機械的な暗記ではなく, 意味的・論 
理的な操作が加わるため, より高い発達段階が必 要となるからであろう。知識の定着という側面か ら地誌学習を考えれば高等学校の段階と小中学校 の段階では方法が異なるべきだということを示し ているといえる.

\section{VI 地誌学習のこれから一欧米の地誌（地理） 学習の動向を踏まえてー}

\section{以上みてきたように，「知識重視の地誌学習」} と「方法重視の地誌学習」は補完関係にあり。両 者を組み合わせることが重要である.

ところで, 日本の地誌学習は, 欧米諸国と比較 して見ると大きな違いがある. 欧米諸国では，世 界認識を育てる学習は, 小学校段階から系統地理 も含めた地理学習全体で行うことになっている (田部・志村・山本・村山 2009). 地誌学習は, 特 定の地域を総合的に扱う単元として位置づけられ ている。つまり, 地誌学習では, 地域の課題を発 見し, 課題に対してどのように対応していくかを 学ぶことに重点が置かれているのである.それは, 身近な地域だけでなく，国家やヨーロッパといっ た州・大陸規模の学習でも同じように行われてい る.

これは,「地誌学」の置かれている立場に関係 があると考えられる。日本においては，国民国家 形成のための教育に主眼が置かれてきた。一方, 欧米諸国では，植民地の開発と管理，経営のため の自然科学と社会科学を統合した学問として発達 した，国内においても，国民教育だけでなく，国 土の開発，管理，経営に関わっており，国土計画 や地域開発，環境政策など通じて国家や地域の将 来像を考えていくうえで重要な学問として認知さ れている（生田 2003）。

さらに，欧米の地理教育のなかで，空間的思考 という概念が重視されつつある.アメリカ合衆国 ナショナルリサーチカウンシル地理科学委員会に よれば，空間的思考は 3 つのレベルに分けられる という (National Research Council 2006). 日常生活 空間レベル, 現実空間レベル, 知的空間レベルで ある。
日常生活空間レベルは，人間が生活していくう えで最も基本的なレベルである。このレベルの空 間情報は日常生活の中で体験的に習得される. 地 理教育の中では，身近な地域の学習がこれに当た る. 現実空間レベルは, 私たちの生活と関係が深 いが，直接体験による知識の獲得ができない空間 である.この空間は, 科学的な方法で知識を獲得 していくことが求められる，地理教育では，身近 な地域の学習以外の学習がこれに当たり,地理 (地 誌）教育の伝統的役割だという．知的空間レベル は, 未来を考える視点である. 地表の文化景観は, 過去の人間の頭の中つまり知的空間で検討され， 地表面に投影されたものと考えられる. とすれば, 未来の地域や世界は, 現代に生きる人類の知的空 間で構想されなければならない，地理学習におい ても単に地域の現状の分析や理解にとどまらず, これからの地域や世界の在り方を考えていくよう な学習をおこなうことで，その意義をさらに高め ることになるというのである。もちろん，この背 景には GIS 技術の発展とそれに伴う情報共有化の 進展がある。

ここから, 日本の地誌 (地理) 学習の特徵や課 題が見えてくる. 第 1 は, 小学校段階の地理（地 誌）教育のあり方である. 日本の地理教育では, 昭和 52（1977）年の学習指導要領以降, 小学校段 階での世界の学習がほとんどない，平成元(1989) 年以降, 若干の復活がみられるが, 低学年から自 地域や自国と対比させながら世界を意識させてい る欧米の地理教育とは差が大きい.

第 2 に, 地誌学習が世界認識の育成を担ってい るという点である. 中学校段階では系統地理学習 がほとんどなく, 地理学習といえば地誌学習とい う状況である. 地誌学習は暗記中心として批判を 受けてきたが，さまざまな工夫，多くの蓄積がな されてきた。こうした蓄積を生かして新たな地誌 学習を考えることが現実的である。一方, 系統地 理学習が一定の地位を占める高等学校では, 中学 校における地誌学習とは役割が異なる. 地域の課 題を発見し，課題に対してどのように対応してい くかを学ぶことに重点が置かれている欧米の地誌 学習の在り方が大いに参考になる. 
第 3 は, 地理 (地誌) 学習の方向性である. 欧 米の地理 (地誌) 教育は, 単に現状の理解にとど まらず，これからの社会をどのように構築してい くかという方向性を明確に有している。これは, 民主主義社会の一員として, 地域社会 - 地球社会 に参画する態度の育成にもつながる。こうした方 向性が重要であることは，日本においても指摘さ れており（たとえば泉 2009），学習指導要領にも 「地域の課題の追求」と明示されてきた。しかし, データや地図等を用いた具体的な学習活動と結び ついていないきらいがある。これは, 児童・生徒 が扱うことのできるデータなどの整備が遅れてい ることやスキルが重視されてこなかったことも一 因である。また,事例が具体的になればなるほど児 童 - 生徒も教員も価值判断, 政治的判断を迫られ る.しかし, 政治的中立性を重視する日本の学校 教育では, 一般的な概念の学習のみで済ませる傾 向にある.

このように検討していくと, 日本の地誌学習の 課題は, 理念や方向性ではなく, どのように現場 の実践を構築するかにある。しかし，それは単に 現場の教員だけの問題ではない. 小学校から高等 学校までの地理学習全体の構成, 教材のもととな るデータの提供や教員と児童・生徒の比率といっ た学習環境の問題も含めて, 教育システムの問題 として検討していく必要があろう.

(2010 年 10 月 29 日受付 2011 年 3 月 14 日受理)

\section{文 献}

荒木一視 2006. 地理ってなに?. 荒木一視・川田

力・西岡尚也『小学生に教える地理』4-27.ナカ ニシヤ出版.

生田真人 2003. 地域研究の発展と地理学. 村山祐司 編『地域研究』1-24. 朝倉書店.

泉 貴久 2009. 地球市民の育成と地理教育. 中村 和郎・高橋伸夫 - 谷内達 - 犬井正編『地理教育 講座第 1 巻 地理教育の目的』191-211. 古今書 院.

岩本廣美 2000. 社会科地理教育における基本的 地名に関する一考察.新地理 $47(3 \cdot 4): 64-73$.
グールド, ホワイト著, 山本正三・奥野隆史訳 1981.

『頭の中の地図一メンタルマップー』朝倉書店.

Gould, P. and White, R. 1974. Mental maps. London: Penguin Books.

小林岳人 1996. 地理の学習目標としてのメンタル マップ. 筑波社会科研究 $15: 11-19$.

斎藤 毅 2003. 世界認識のための地誌教育.『発 生論的地理教育論一ピアジェ理論の地理教育 論的展開』46-48.古今書院.

(財) 総合初等教育研究所 2008. 『社会について の基礎的知識の習得に関する研究』.（財）総 合初等教育研究所.

篠原昭雄 1984. 地理教育と国際理解. 『地理教育 の本質と展開』55-62.明治図書.

白井哲之 2000. 高校地理の新学習指導要領を巡る 課題. 日本地理教育学会編『新学習指導要領と 地理教育』2-6. 日本地理教育学会.

田部俊充 - 志村 喬 - 山本 充 - 村山朝子 2009 . 外 国における地理教育. 中村和郎 - 高橋伸夫 - 谷 内達 - 犬井正編『地理教育講座第 1 巻 地理教 育の目的』古今書院.117-170.

中央教育審議会 2008. 小学校, 中学校, 高等学校 及び特別支援学校の学習指導要領の改善につ いて (答申). http://www.mext.go.jp/a_menu/ shotou/new-cs/news/20080117.pdf

手塚 章 1988. 地理学の革新と伝統. 中村和郎 · 高橋伸夫編『地理学への招待』168-191.古今書 院.

西脇保幸 1993.『地理教育論序説』二宮書店. 日本地理学会地理教育専門委員会 2005 . 『大学 生・高校生の世界認識の調査報告』 http://www.ajg.or.jp/organization/committee2003/c hirikyouiku050222.pdf

日本地理学会地理教育専門委員会 2008. 『大学 生・高校生の地理的認識の調査報告』 http://www.ajg.or.jp/chirikyouiku20080319.pdf. 矢ヶ㠃典隆 2003. 地域研究の課題と将来. 村山祐 司編『地域研究』170-191.朝倉書店. 矢嶋仁吉 1977. 地誌学習の基本問題. 矢嶋仁吉 位野木寿一・山鹿誠次編『現代地理教育講座第 3 巻 地誌学習の基本問題』1-14.古今書院. 
山口幸男 1994. 地理意識発達の実証的究明. 群馬 大学教育学部紀要人文社会科学編 $43: 121-152$.

National Research Council of the National Academies.
2006. Learning to think spatially. Washington,

D.C.: The National Academies Press.

\footnotetext{
<著者略歴 $>$

秋本 弘章（あきもと ひろあき）

1962 年埼玉県生まれ。埼玉県公立高等学校, 東京学芸大学附属高等学校教諭を経て, 現在獨協大学経済学 部教授.

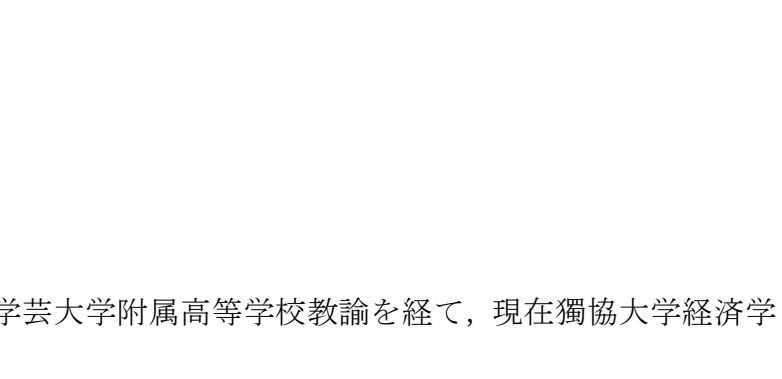

